\title{
Upravené skalní výchozy a otázka megalitizmu v těžební oblasti Krumlovského lesa
}

\section{Modified rock exposures and question of megalithism in the „Krumlovský les" extraction area.}

\section{Martin Oliva}

\begin{abstract}
Abstrakt
S nápadnými skalkami s různými prohlubněmi a rýhami byly vždy spojovány představy o obětních kamenech a záhadných poselstvích. V českých zemích se však většinou nacházejí v hornatém terénu, tedy bokem pravěkého osídlení. Výjimkou je pahorkatina Krumlovského lesa na jižní Moravě. Jeho podloží tvoří granodiority, na něž nasedaly jurské vápence, později denudované. Dochovaly se z nich pouze rohovce, redeponované do sedimentů miocenního moře. Ty vždy tvořily základ štípaných industrií v širokém okolí a od mezolitu do starší doby železné se intenzívně těžily. Vrchol těžby spadá do starší doby bronzové, kdy zde byly odtěženy a později opět navršeny vrcholové partie dvou sousedních hřbítků. Hlavně od té doby byla těžba motivována spiše společenskými a náboženskými než praktickými pohnutkami. Současně se tu vyskytují nápadné skalky a skupiny balvanů, obklopené štípanou industrií, z nichž některé jsou upravené či přemístěné. Je tedy zřejmé, že byly důležitou součástí sakrální krajiny, i když bez souvislostí se západoevropským megalitizmem.
\end{abstract}

\section{Klíčová slova}

Krumlovský les; jižní Morava; těžba rohovce; skalní výchozy; skupiny balvanů; megalitizmus

\begin{abstract}
People have always tended to link images of sacrificial stones and mysterious petroglyphs to conspicuous rocks with various recesses and grooves. In the Czech lands, however, these are mostly found in mountainous terrain, i.e., beyond prehistoric settlement areas. With its bedrock formed of granites on which sat Jurassic limestones, the Krumlovský les upland in south Moravia is an exception. The Jurassic limestones that subsequently underwent denudation were preserved only in the form of cherts, redeposited into sediments of the Miocene sea. These cherts were always the fundamental raw material of chipped industries in the wide surroundings and kept being intensely extracted since the Mesolithic to the Hallstatt Age. The exploitation culminated in the Early Bronze Age, when top parts of two neighbouring small crests were removed by extraction and thrown back again later. Particularly since that era the motives for extraction were more likely social and religious than practical. Conspicuous rocks and groups of boulders,
\end{abstract}


some of them modified or relocated, occur in extraction areas, and are surrounded by chipped industry. It is evident these were an important part of sacred landscape, although without links to the Western European megalithism.

\section{Key words}

Krumlovský les; Southern Moravia; chert mining; rock outcrops; groups of boulders; megalithism

\section{1. Úvod}

Vyčnívající skalky, často roztodivných tvarů nebo s nápadnými prohlubněmi a rýhami, poutaly pozornost odedávna, a od samých počátků archeologie s nimi byly spojovány představy o obětních kamenech a záhadných nápisech (Sklenář 1977, 35-46, 127-138).

V našich končinách se však tyto skalní útvary nacházejí většinou v hornatém terénu, tedy bokem pravěkého osídlení. To je jejich společným znakem pro Čechy (Woldřich 1896) i pro Moravu (Rzehak 1906; Skutil 1947). Nechybějí sice skalní útvary, ba celé takové krajiny v místech archeologicky bohatých (Pavlovské vrchy, Moravský kras), ty jsou však vápencové, a jak si povšimnul již Anton Rzehak (1906), v sedimentárních horninách se sledované jevy nevyskytují. Regiony s vyčnívajícími skalkami a balvany ze žuly (která do nápadných tvarů zvětrává nejčastěji) se uvnitř dějišţ pravěkých aktivit vyskytují velmi vzácně. Jednou z těchto výjimek je pahorkatina Krumlovského lesa na jižní Moravě.

\section{Geografie Krumlovského lesa a těžba rohovce}

Krumlovský les je součástí hrástovité Leskounské vrchoviny mezi Dyjskskosvrateckým úvalem a jižní částí Boskovické brázdy (Demek - Mackovčín edd. 2006, 251-252). Nejvyššího vrcholu dosahuje ve svém středu plochou kótou Stavení (415,4 m), k J vybíhá do výrazného, dnes již většinou odtěženého vrchu Leskoun (371 m), a ze SZ s ním sousedí rozsáhlé návrší Réna (319,2 m) nad Ivančicemi. Na obou kopcích se rozkládala důležitá pravěká hradiska. Podloží Krumlovského lesa tvoří granodiority brněnského batolitu, na něž nasedaly jurské vápence, později denudované (Príchystal 2010). Rohovce, které se v nich vytvořily, se po transgresi miocenního moře uložily hlavně v píscích a v písčitě-detritických sedimentech. Již od přelomu starého a středního paleolitu tvořily místní rohovce základ štípaných industrií všech zdejších bohatých nalezište, většinou žel jen povrchových. Využívání rohovců vrcholí ve starší fázi mladého paleolitu (szeletien a aurignacien), poté ustává a obnovuje se až v mezolitu. V té době, stejně jako v neolitu a později je místní rohovec (vyskytující se ovšem i na mnoha jiných místech až po severní okraj brněnské kotliny: Přichystal 2009, 72) zpravidla nejčastější surovinou štípaných nástrojů na jižní Moravě a v přilehlé části Dolního Rakouska. V samotném Krumlovském lese, konkrétně v jeho JV části byl těžen od mezolitu do starší doby bronzové takřka nepřetržitě, a po hiátu ve střední až pozdní době bronzové, kdy v těžních revírech probíhaly jiné aktivity, se těžba obnovila ještě ve starší době železné (Oliva 2010). Tato těžba vykazovala po celou dobu výrazné společenské motivace, protože kámen na výrobu potřebných nástrojů tu bylo vždy možno nasbírat v libovolném množství na povrchu. Již mezolitická těžba svědčí o mimořádném soustřed'ování a setrvávání pracovníků na jednom místě, což bychom 


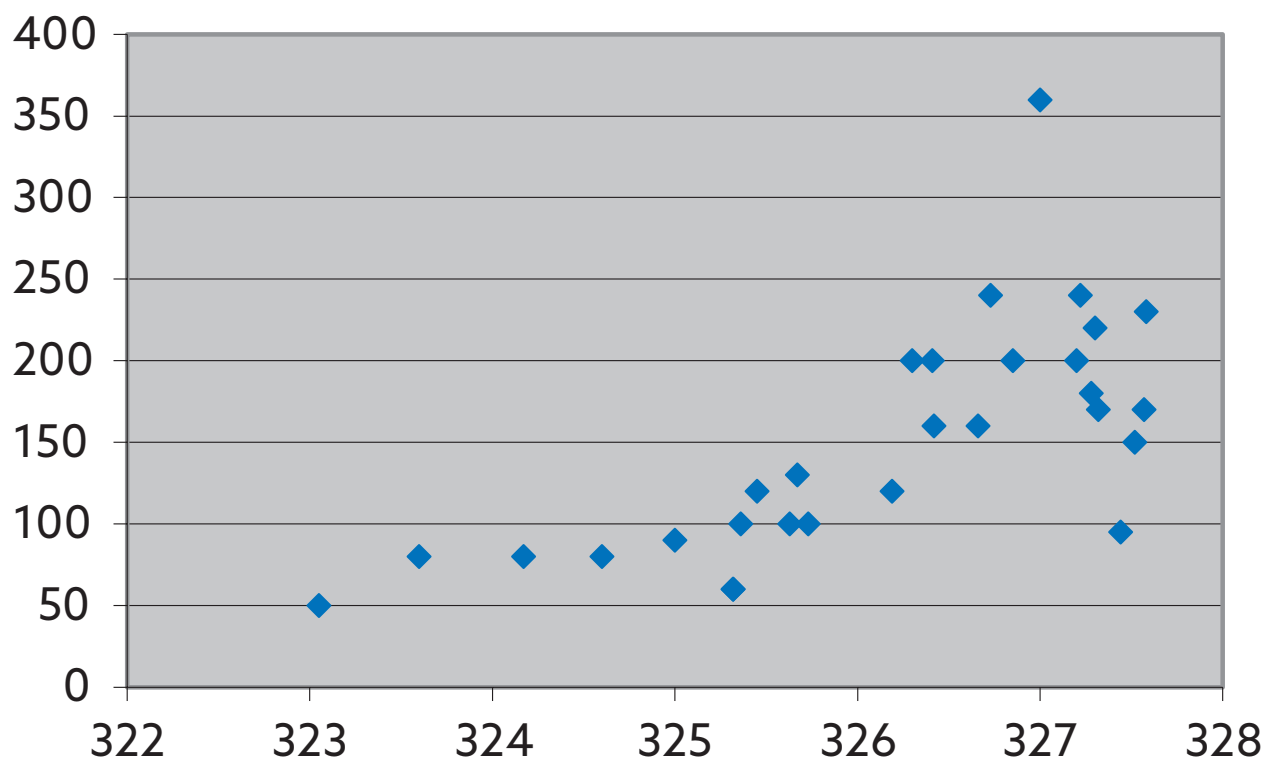

nm.v. (m) /mocnost haldy (cm)

Obr. 1. Krumlovský les, východní část I. revíru. Mocnost haldy rubanin (na ose y) narůstá směrem do svahu (dle nm. v. na ose $x)$.

Abb. 1. Krumlovský les (Kromauer Wald), Abbaurevier I - Ost. Die Mächtigkeit der Abraumhalde (Achse y) steigt bergaufwärts (nach der Seehöhe auf Achse x).

u lovců-sběračů neočekávali (Oliva 2015; 2020). Předpokládaný následek tu tedy předchází domnělé příčině, tedy usedlému způsobu života v důsledku přijetí zemědělství. Těžba vrcholí ve starší době bronzové, kdy se na ploše desítek hektarů nacházely stovky šachet, hlubokých až 6 metrů (bez nadložní haldy), často o několikametrovém průměru. Před hloubením šachet byl terén dvou jižních revírů I a II snížen protěžením svrchních písčitých sedimentů s rohovci. Po ukončení těžby byla rubanina ze svahů nanesena zpět na vrcholové partie hřbítků, předtím snížené, a to v mocnosti jednoho až tří metrů (Oliva 2019, mapa 2-4, 161 sq.). Mocnost nánosu stařin totiž zřetelně narůstá směrem proti svahu a vrcholí na temenech, přičemž všude překrývá ústí starobronzových (a ovšem i starších) šachet (obr. 1). Z hlediska provádění těžby i postdepoziční mechaniky sedimentů by něco takového bylo zcela nepřirozené, jde tedy nepochybně o důsledek záměrného jednání, motivovaného jinak než praktickými požadavky extrakce. Po celou dobu těžby probíhalo masové štípání vytěženého rohovce, který se házel zpět do šachet nebo sypal po svazích do údolí, a to v objemu tisíců tun. Tato masová činnost vrcholila během finální fáze zpětného nanášení sedimentů, protože s největším množstvím štípané industrie se vždy setkáváme v horních úrovních násypů (Oliva 2019, 168-169). Do okolí se z naštípaného množství rohovců (a tehdy také zvláště vyhledávaných rohovcových brekcií) odnesla jen nějaká promile, a to většinou jen na stanoviště nějakého zvláštního postavení. 
Mezi ty jistě patří hradiska na Leskounu, na Cezavách u Blučiny a na skalní výspě s mohutným shromažd'ovacím domem u Budkovic, které patří ovšem již kultuře věteřovské (Stuchliková 1990; Stuchlik 2001). Jediné podstatnější odbytiště těžby se však rozkládalo v trati Nad lukama u Kubšic, kde se vyskytuje obrovské množství poměrně expertní industrie z místních rohovců a rohovcových brekcií. Terén o rozloze min. pěti hektarů sloužil nepochybně jako shromaždiště těžařů a štípačů únětické kultury (Oliva 2010, 279-281). Dále, a to až do jižních Čech a do Slezska, se šíriily pouze srpové čepele, nalézané často v situacích s rituálními konotacemi (Oliva 2019, 179-180). Ve starší době bronzové byly prakticky vždy vyráběné z rohovců a brekcií typu Krumlovský les (Oliva 2003, 39; Kañáková Hladiková 2013, 82-83), takže zřejmě odkazovaly k nějaké přidané (magické?) hodnotě místa svého původu.

$\mathrm{Na}$ rozdíl od jiných míst se tedy v Krumlovském lese spojuje poloha uprostřed bohatě osídleného území, sama intenzívně využívaná, s dlouhou tradicí a s výraznými projevy masových aktivit symbolického významu, na níž se navíc vyskytují přirozené skalní výchozy a skupiny nápadných balvanů. Kde jinde než zde tedy hledat skalní útvary se stopami antropických manipulací pravěkého původu.

\section{Vyčnívající skalní útvary}

Granodioritové podloží Krumlovského lesa (obr. 2) vyráží na mnoha místech na povrch v podobě útvarů, jimž pozdější eroze dala tvar vyčnívajících vertikálních skalek (torů), plochých či zaoblených balvanů, mrazových srubů a ojediněle i skalních hřibů (obr. 3). Tory vznikly selektivním zvětráváním výchozů horniny s vertikální tektonikou (Migoň - Roštínský 2003, obr. 4 a 7), kamenná moře rozvětráváním skal za spoluúčasti mrazu, který má na svědomí též mrazové sruby pod Rénou (Demek 1960, obr. 6-7). Skupiny velkých kamenů jsou na rozdíl od předchozích útvarů petrologicky dvojího původu: jednak jsou to méně zaoblené, často plotnovité bloky rohovcových brekcií (Oliva 2010, foto IV), vzniklých za starotřetihorního zvětrávání, jednak granodioritové balvany, jejichž zaoblenost mohla souviset i s přirozeně oblými tvary v granodioritovém podloží (obr. 2), byla však dotvořena erozí. Skupiny těchto balvanů někdy připomínají pravěké dolmeny až chodbové hroby, z nichž některé se nacházejí na místech odlehlých od archeologických nálezů (Oliva 2010, foto III), jiné jsou naopak obklopené štípanou industrií, takže jistě neunikly pozornosti pravěkých těžařů (obr. 4). Nejvýraznější skálou Krumlovského lesa je tzv. Čertova díra na severním okraji Vedrovic s tzv. „obětní mísou“ na nejvyšším balvanu. $\mathrm{V}$ jiné nápadné skalce na jižním svahu kóty 348 západně od jmenované obce se vyskytuje jeskyňka v podobě vodorovné štěrbiny, do níž se dá vplazit. Na vyčnívajících granodioritech nechybějí ani žlábkové škrapy a pukliny, které by minulým generacím archeologů mohly připomínat umělé výtvory či znaky (Demek 1960, obr. 3-5).

\section{Balvany a skalky v lidském světě}

Lze očekávat, že pozornost lidí poutaly ty útvary, které se nacházely v blízkosti dějiště masových aktivit, tj. těžby rohovce, vykonávané zde nejméně od počátku mezolitu do starší doby železné. Některé z nich nenesou žádné stopy lidské činnosti, ale skýtají vhodné sedátko pro pravěké štípače a jsou proto obklopené mimořádným množstvím výrobního odpadu. U jednoho takového „sedátkového“ balvanu ve II. revíru (Oliva 2010, mapa 4: B, foto VIII) byla celá produkční oblast roku 1971 objevena. Jen několik metrů odtud leží skupina plochých granodioritových balvanů II-5 a osamocený balvan 


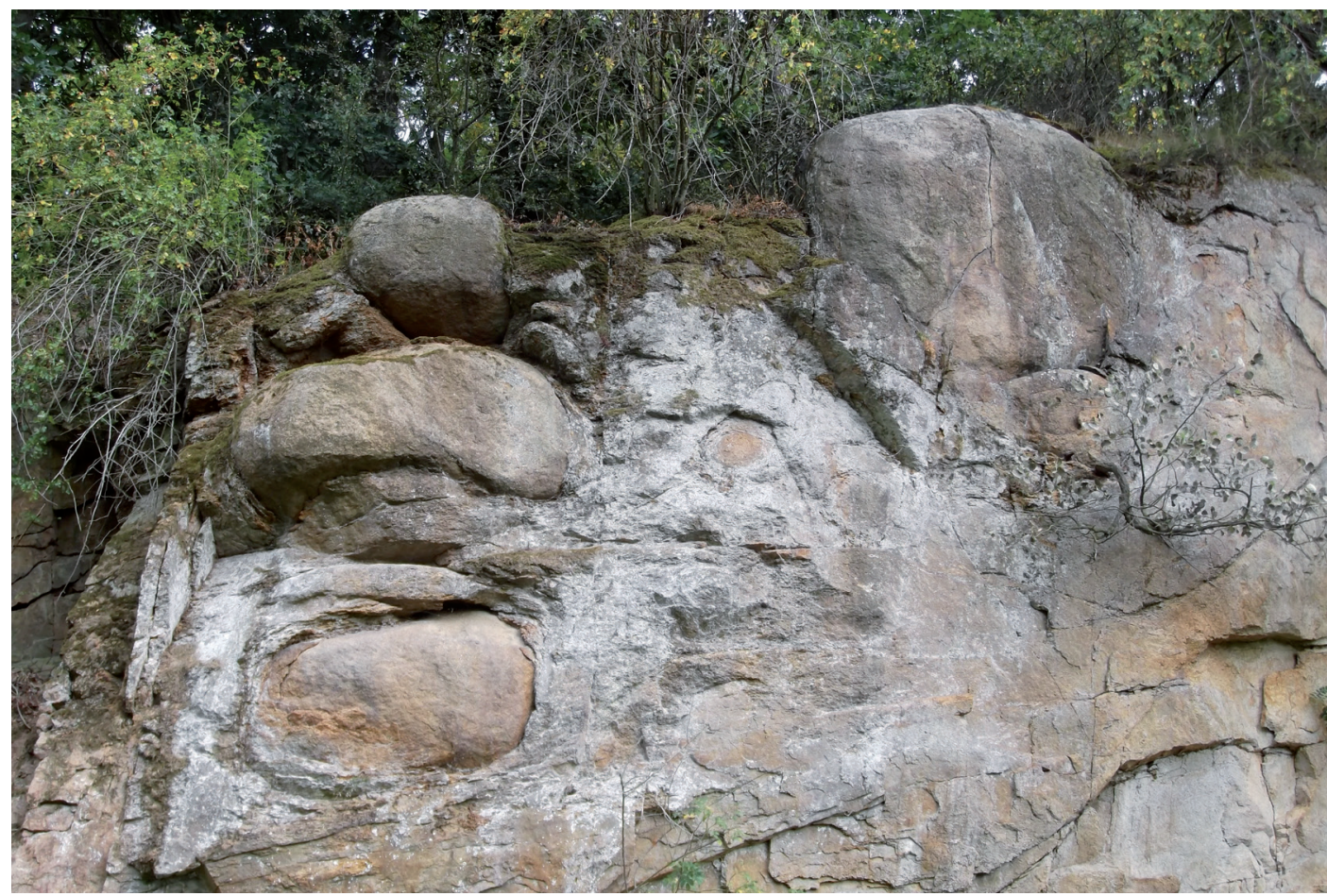

Obr. 2. Vyvřelé granodioritové podloží Krumlovského lesa vytváří kulovité tvary, vyčnívající až na povrch. Foto M. Oliva.

Abb. 2. Die eruptive granodioritische Sohle des Kromauer Waldes bildet kugelige Gebilde, die bis zur Oberfläche hinausragen. Foto M. Oliva.

II-1 (Oliva 2010, foto 4, 5 a 13, plán 2, mapa 4). Jsou obklopeny velmi nekvalitní a spíše drobnotvarou štípanou industrií, možná z mladší doby bronzové, protože jeden okraj nádoby je tuhován (Oliva 2010, obr. 85: 8).

Poloha $\mathrm{s}$ tř́šstěnými rohovci (s druhotně použitým zlomkem eneolitického sekeromlatu), mocná $60 \mathrm{~cm}$, spočívala na popelovité vrstvě, pokrývající ploché skalní podloží (Oliva 2010, 153-154, obr. 86). Z mladší a pozdní doby bronzové stopy těžby v Krumlovském lese chybí, ale docházelo k ukládání starší štípané industrie do polozasypaných šachet, kde ji doprovází mnoho uhlíků a v šachtě II-9 též přenesené nádoby s popelem a zlomky bronzových jehlic (Oliva 2010, 195-199). Tyto rituální aktivity se tu patrně neodehrávaly samostatně, ale provázely pastevectví, k němuž se řídký dubový les hodil stejně jako v následující starší době železné. Štípanou industrií byl obklopen též izolovaný blok rohovcové brekcie v I. revíru, a její nejvyšší koncentrace ležela právě pod nejpříhodnějšém sedátkem, které nepochybně ocenil i pravěký štípač (Oliva 2010, foto 2, plán 1). Pouze jeden z těchto plochých bloků, jež vzhledem k jejich funkci můžeme metaforicky nazvat pravěkým nábytkem, je poznamenán lidskou rukou. Vyskytuje se ve skupině II-3 (Oliva 2010, mapa 4: C, plán 7, foto 11, 22 a LV), kde je na okraji vodorovné plochy zaoblené granodioritové plotny, vyčnívající ze skalního podloží, vyryt pravidelný kroužek (obr. 5). Vykazuje 


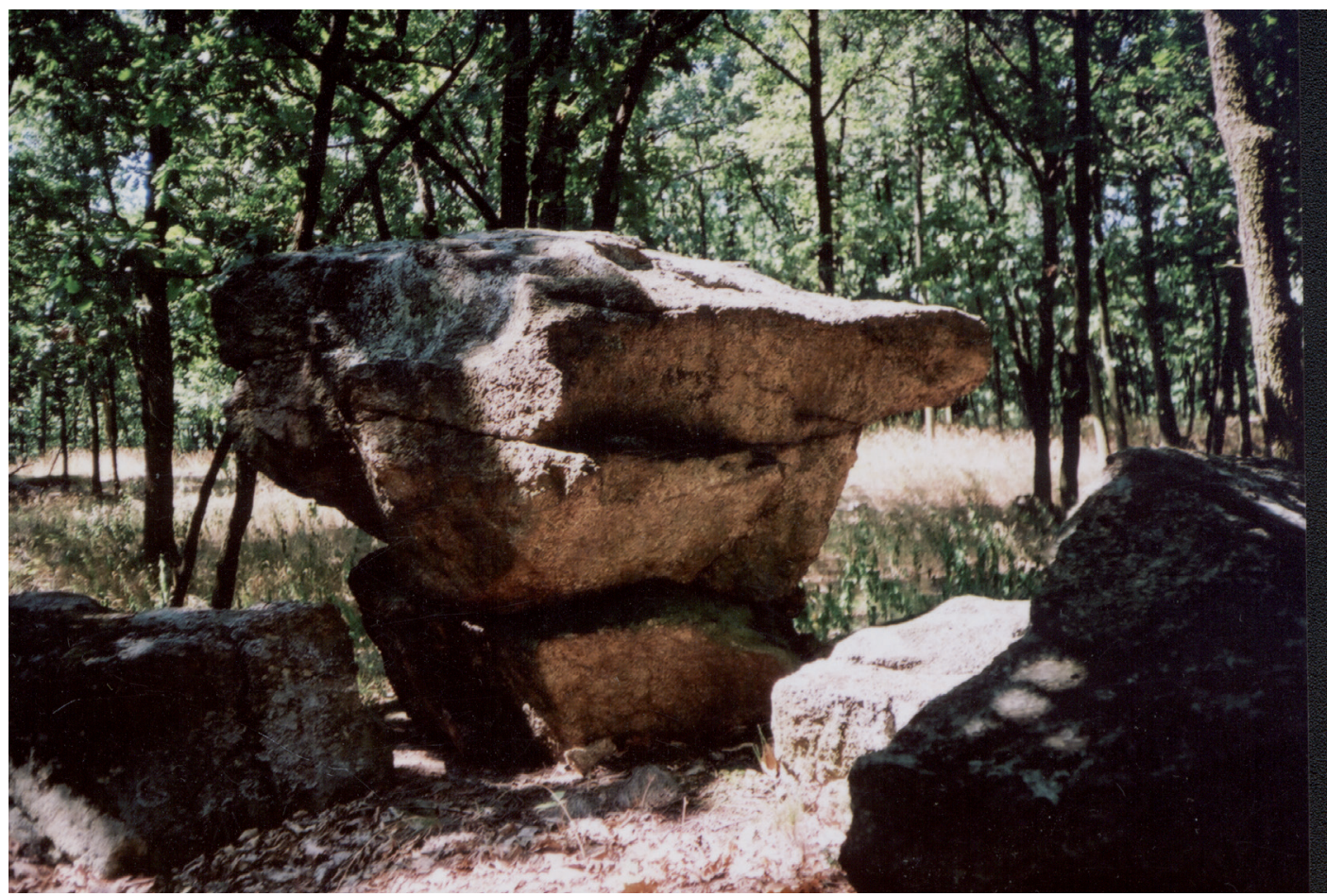

Obr. 3. Skalní hřib v jižní části Krumlovského lesa. Foto M. Oliva.

Abb. 3. Felsenpilz im Südteil des Kromauer Waldes. Foto M. Oliva.

zcela pravidelný tvar a na ostatních balvanech se žádné podobné tvary prrírodního původu nevyskytují. Povrch rýhy je dnes ovšem už stejně ovětralý jako povrch balvanu. Přímo pod ním se ve skalce nacházejí přirozené škvíry, v nichž se ukrývala štípaná industrie a několik malých střepů, dle dobrozdání S. Stuchlíka nejspíse únětické kultury. Ze dvou metrových čtverců na této straně skalky, prozkoumaných na sterilní zvětralinové podloží v hloubce $60 \mathrm{~cm}$, byl zpracován jen obsah subčtverce $4 / \mathrm{Da}$ o rozměrech $50 \times 50 \mathrm{~cm}$. Ten přiléhal ke svislému boku balvanu, tedy i k puklinám se zmíněnými střípky, a obsahoval $580 \mathrm{ks}$ industrie o váze $5,6 \mathrm{~kg}$ (Oliva 2010, tab. 32c). Složení souboru poněkud menších artefaktů, než je v okolí obvyklé, se vyznačuje zvýšeným množstvím výrobního odpadu, absolutní převahou nekortikálních úštěpů a poněkud vyšší frekvencí retušovaných kusů. Mezi jádry převládají načaté kusy suroviny (14) a naopak reziduální exempláře (13). Tenké diskovité jádro s rovnoběžnou těžbou na obou plochách a úzce kýlovitý tvar (Oliva 2010, obr. 41: 1 a 4) mají analogie na sídlišti únětické kultury v Kubšicích; na prríhodném skalním bloku se štípači ovšem mohli usazovat opakovaně.

Za dalšími balvany s umělými zásahy se musíme vydat $\mathrm{k}$ velmi nápadnému výchozu asi $80 \mathrm{~m}$ západně od III. těžního revíru (obr. 6 a 7; Oliva 2010, foto XCVIII-IC; 2019, foto 91-92). Nejsevernější podlouhlý balvan v ústřední skupině (Oliva 2010, foto C-CII) asi stával svisle, protože část jeho povrchu, odhalená až výzkumem, je ovětralá stejně jako část horní (spodky ostatních balvanů, korodované humusem, jsou vždy narušenější než části nadzemní). Na užším 


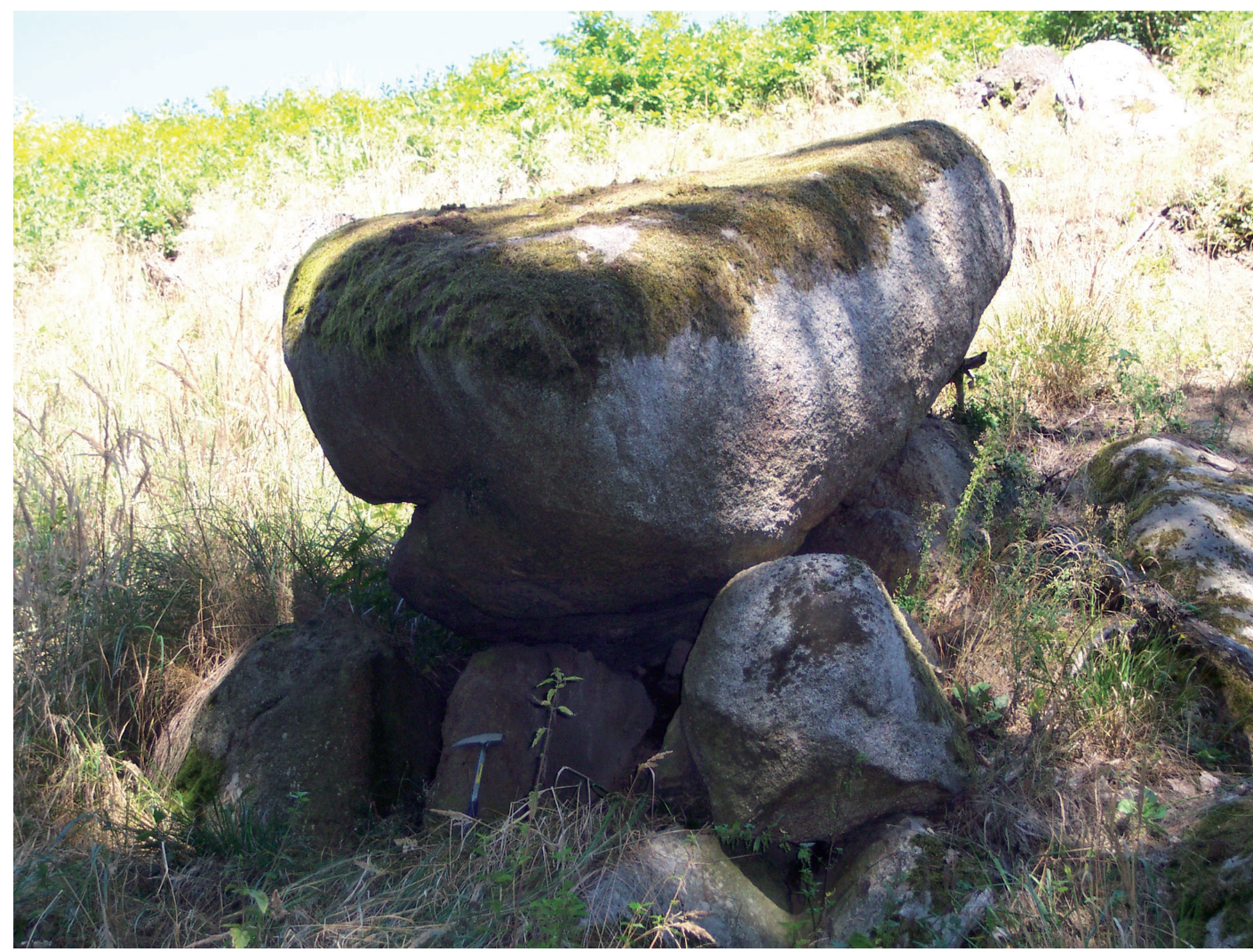

Obr. 4. Skupina žulových balvanů na úpatí VI. těžebního revíru připomíná pravěký dolmen. Foto M. Oliva.

Abb. 4. Die Gruppe von Granitblöcken am Fuß des VI. Abbaureviers erinnert auf einen urzeitlichen Dolmen. Foto M. Oliva.

konci kamene pozorujeme dva kruhovité tvary, $\mathrm{V}$ plošně prozkoumaném areálu západně před nepochybně umělého původu (obr. 6 vlevo; 7; balvany se v hloubce ca 20-30 cm rozprostíral 8: A; Oliva 2010, foto CII; 2019, foto 92, 100). dosti souvislý horizont plošších kamenů, připoTento názor zastávali i všichni geologové, kte- mínající dlažbu (Oliva 2010, foto CV). Asi $21 \mathrm{~m}$ ří místo navštívili (např. Přichystal 2010, 386). S od kamene - „mensy“ se nachází další balvan, $\mathrm{V}$ čele skupiny leží balvan s rovnou horní plo- tentokrát naopak zaoblený. K severu z něj vychou, který evokuje představu mensy (obr. 8: bíhá boční výběžek, upravený do podoby hlaB), u SV okraje se tyčí další nápadný kámen, vičky nebo falu (Oliva 2010, foto CIII-CIV). zvaný „mitra“ (obr. 6; 8: C). Výzkumem areá- Celý obvod výčnělku obepíná hluboká rýha, lu v roce 1998 jsme zjistili mnoho přinesených přerušená jen na jediném místě. Kromě řídké fragmentů rohovců, většinou neopracovaných, štípané industrie, odpovídající nejspíše starší a jeden nevýrazný pravěký střep. Zdaleka největ- době bronzové (Oliva 2010, obr. 83: 7-9), se ve ší koncentrace zřejmě úmyslně, ale zcela nahodile roztř́ístěných velkých rohovců, se nacházela právě u paty zmíněného podlouhlého balvanu. výkopu objevily četné zlomky picí keramiky ze 14. století (Oliva 2010, obr. 92, det. Z. Měchurová). Ta patrně souvisí s čižbou, jíž nasvědčuje 


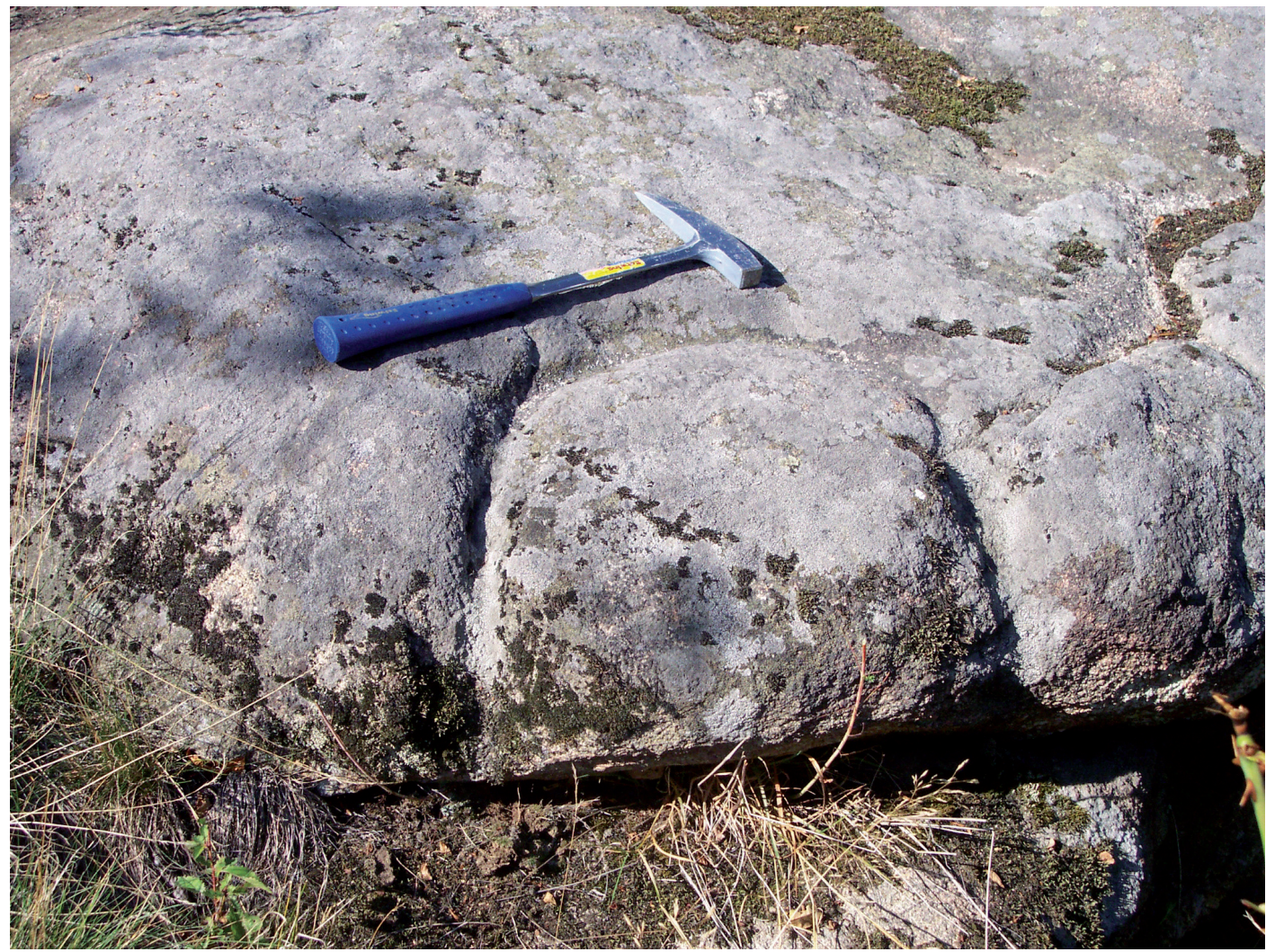

Obr. 5. Plochý výchoz žuly III-5 s vyrytým kruhem byl obklopen štípanou industrií. Foto M. Oliva.

Abb. 5. Der flache Granitaufschluss III-5 mit graviertem Ring war mit Spaltindustrie umgeben. Foto M. Oliva.

otvor v horní ploše balvanu před „mitrou, (obr. 6 za trasírkou; 8: D) do něhož byl asi zapuštěn kovový kroužek na dravce, jak je tomu dosud v nedaleké skalce nad západní částí I. těžebního revíru. Té se dle místního pamětníka říkalo „U malého kroužku“ a nějakému jinému místu poblíž (patrně tedy popsané skupině) „U velkého kroužku“. Výzkum svahu pod jižním okrajem těchto částečně odtěžených skalek s kótou 346 (Oliva 2010, mapa 3, foto VII; 2019, foto 46 a 90) přinesl řadu keramických střepů ze starobronzových nádob. Je zajímavé a příznačné, že i v okolí této skalky (U malého kroužku) najdeme stopy pozdějších aktivit. Jeden drobný fragment tuhovaného okraje $\mathrm{z}$ bezprostředního okolí skalky spadá patrně do mladší doby bronzové až halštatské, a v těžní jámě I-1-1 na úpatí svahu se v popelovitém horizontu $40 \mathrm{~cm}$ pod vrškem zásypu pinky vyskytly laténské střepy (Oliva 2010, obr. 85: 1-4). Že Keltové věnovali pozornost nápadným terénním útvarům se starou tradicí lidské přítomnosti si povšimnul již W. Dehn (1982) a později k tomu z našeho území přinesli nové doklady J. Waldhauser (1994; Waldhauser - Koldová 2006), J. John (2003, 82) a jiní.

Další kámen není nijak upraven, ale s největší pravděpodobností byl přemístěn a má proto k megalitickému fenoménu nejblíže (obr. 9). Na koruně svahu v dolní části VI. těžního revíru 


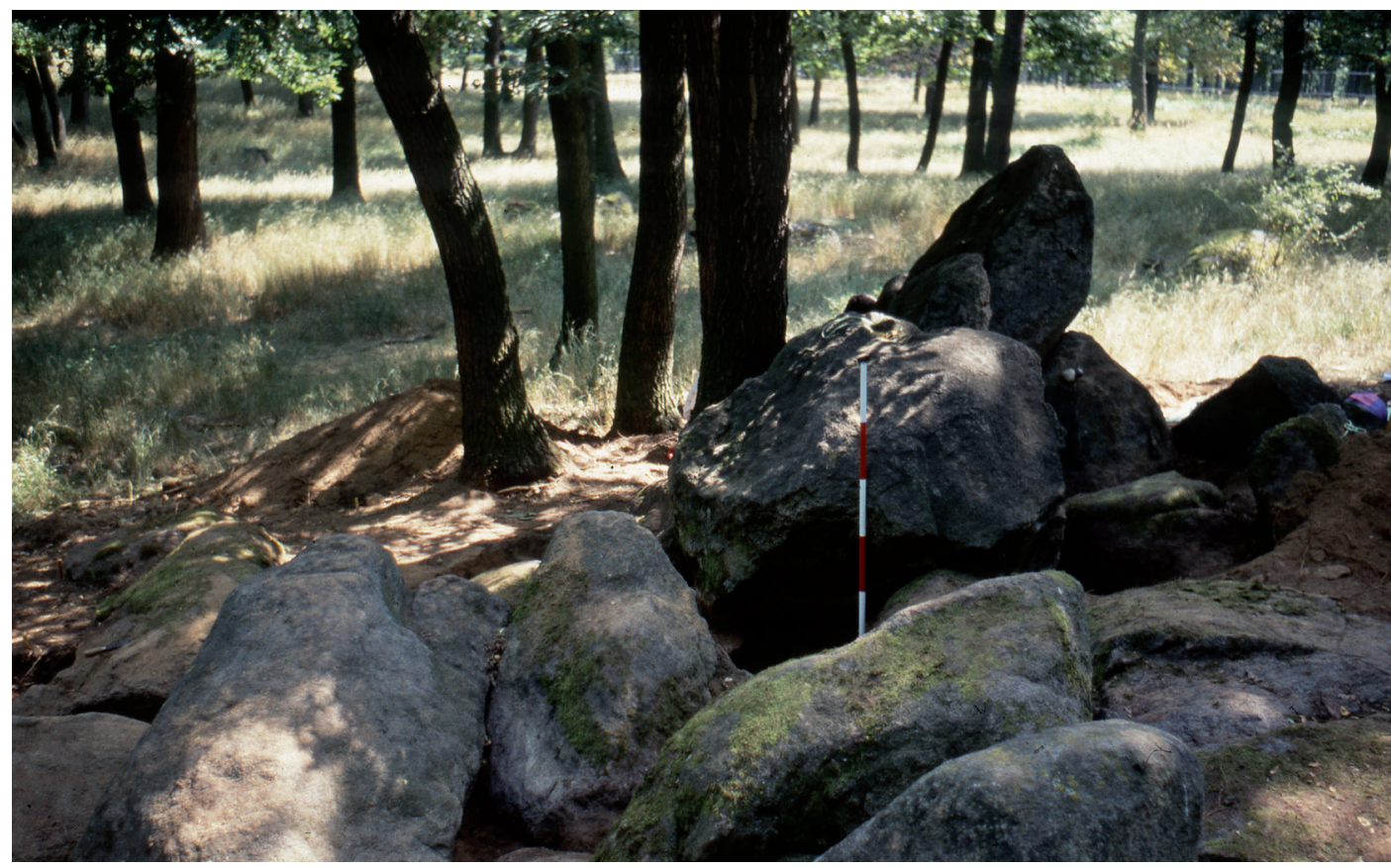

Obr. 6. Skupina žulových balvanů u III. revíru, pohled od JZ. Foto M. Oliva.

Abb. 6. Gruppe von Granitblöcken am III. Revier, Südwestansicht. Foto M. Oliva.

leží asi metrový balvan hrubé rohovcové brekcie (Oliva 2010, foto LXVIII). Balvan nejeví stopy opracování, ale označuje místo, vytěžované až osm metrů hlubokými šachtami nejméně od mladšího lengyelu po starší dobu železnou. Jinde převládající těžba ze starší doby bronzové na tomto svahu s jistotou doložena není, alespoň ne střepy či radiometrickými daty. Pavel Roštínský (2009, 38) připouští samovolný posun kamene po svahu tzv. creepem, je ale nepravděpodobné, že by se z markantní skupiny podobných balvanů, skutečně ležící asi 700 m východněji, sám od sebe přemístil jen jeden, navíc po svahu o průměrném sklonu jen 10 stupňů. O jeho záměrném přemístění na dnešní místo svědčí ostatně skutečnost, že leží na prokopaném sedimentu s úštěpy (Oliva 2010, profil 1). Je však možné, že balvan ležel původně blíže - tomu nasvědčuje jeho poměrně nenápadný tvar, zatímco na vzdálené plošině byly snad na výběr i kusy nápadnější, tj. třeba protáhlejší. Kdy k transportu došlo, je otázkou, ale v šachtě č. 4, jejíž ústí se otvíralo o 8 m níže po svahu, se našly skelety dvou malých žen a novorozence, pohřbených během mladšího stupně lengyelské kultury (Oliva 2010, 29 sq., plán 3, foto CVIII). Pokud měla mít pracná instalace balvanu, postrádající praktický smysl, nějaký význam symbolický, bylo to nejspíše při této př́ležitosti.

Žádné stopy opracování či transportu naproti tomu nevykazuje nápadný útvar, připomínající od spodu dolmen (obr. 4), který se nachází u dna údolí na úpatí protěženého svahu právě pod zmíněným balvanem (Oliva 2010, mapa 7: A, foto 7 a XV). I když je přirozeným produktem zvětrávání granodioritového podloží (Roštínský 2009, 35), nemohl jeho nápadný tvar uniknout pozornosti pravěkého člověka. 


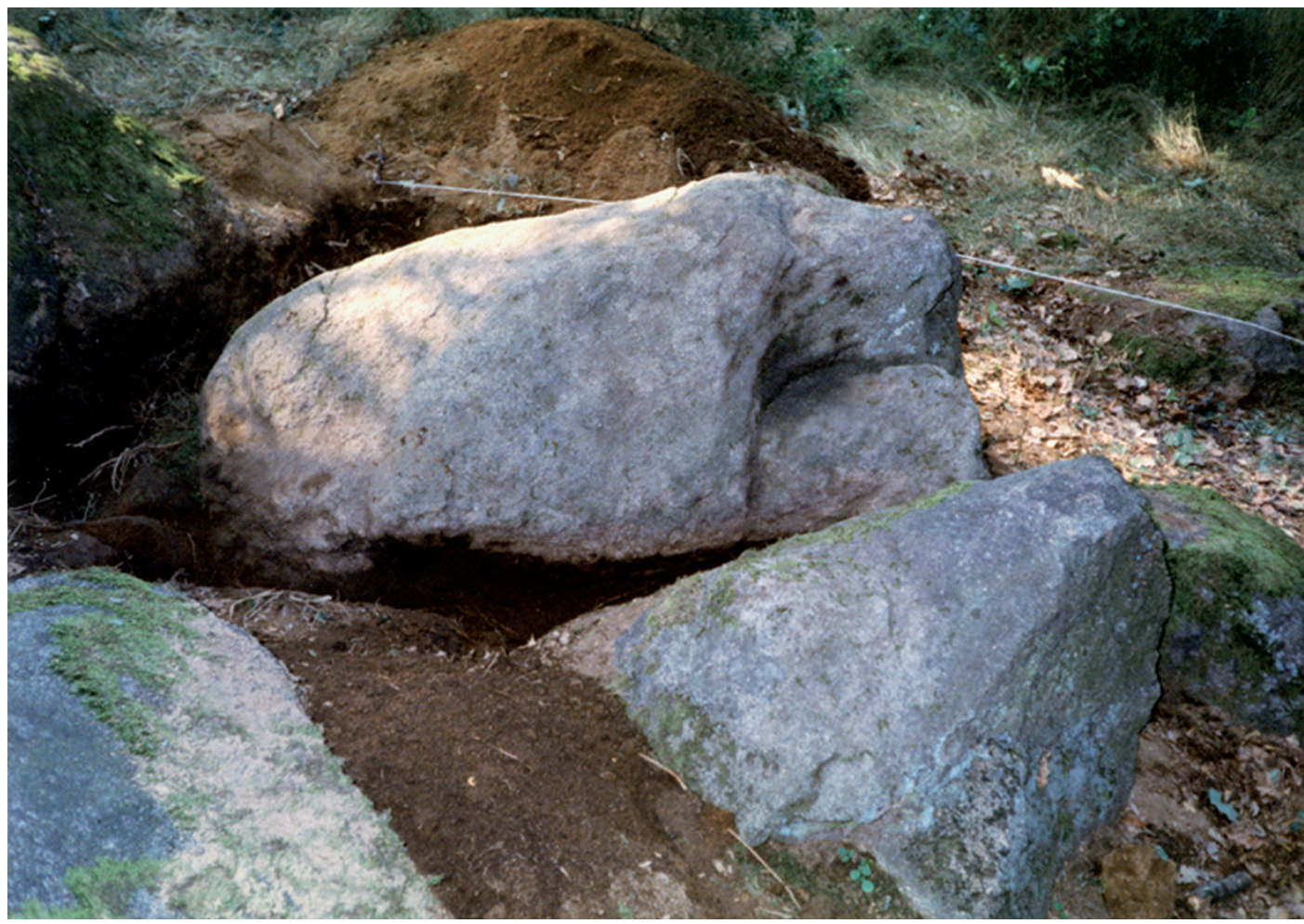

Obr. 7. Podlouhlý balvan se dvěma vytesanými hlavami na severním okraji hlavní skupiny žulových balvanů. Foto J. Homolka.

Abb. 7. Länglicher Steinblock mit zwei ausgemeißelten Kopfen am Nordrand die Hauptgruppe von Granitblöcken. Photo J. Homolka.

V přilehlém údolním úseku se v zářezu periodického potůčku nacházejí nevýrazné pravěké střepy, dle hmoty snad ze starší doby železné, těžba na svahu spadá na sám počátek a sklonek eneolitu a do kultury horákovské. Přímo pod útvarem vede údolím stará erodovaná cesta a případný výzkum by tu byl asi bezvýsledný.

Zatímco tato severní strana údolí zůstala ušetřena novodobých zásahů a dochovala se v podstatě tak, jak byla po skončení těžby a osídlení v době halštatské opuštěna, úbočí protějšího jižního svahu, s rozsáhlým těžebním areálem $\mathrm{V}$ na temeni, bylo $\mathrm{v}$ minulých staletích zcela odtěženo (Oliva 2010, mapa 7: B). Těžbu kamene vyvolaly nápadné vyčnívající skály, kte- ré mohly být zajímavé nejen krajinářsky, ale nepochybně si jich všímali i pravěcí těžaři. Zda jim sloužily i jako dějiště rituálů, prováděli na nich zásahy, nebo mezi nimi uložili nějaké depoty, se žel již nedozvíme.

\section{Závěr}

Doložené manipulace s balvany v prostoru II. a III. těžního revíru mohly samozřejmě vzniknout kdykoli v průběhu pravěku i v historické době. S největší pravděpodobností ovšem vznikly tehdy, když se v okolí vyskytovalo největší množství lidí, a to při masových a velmi 


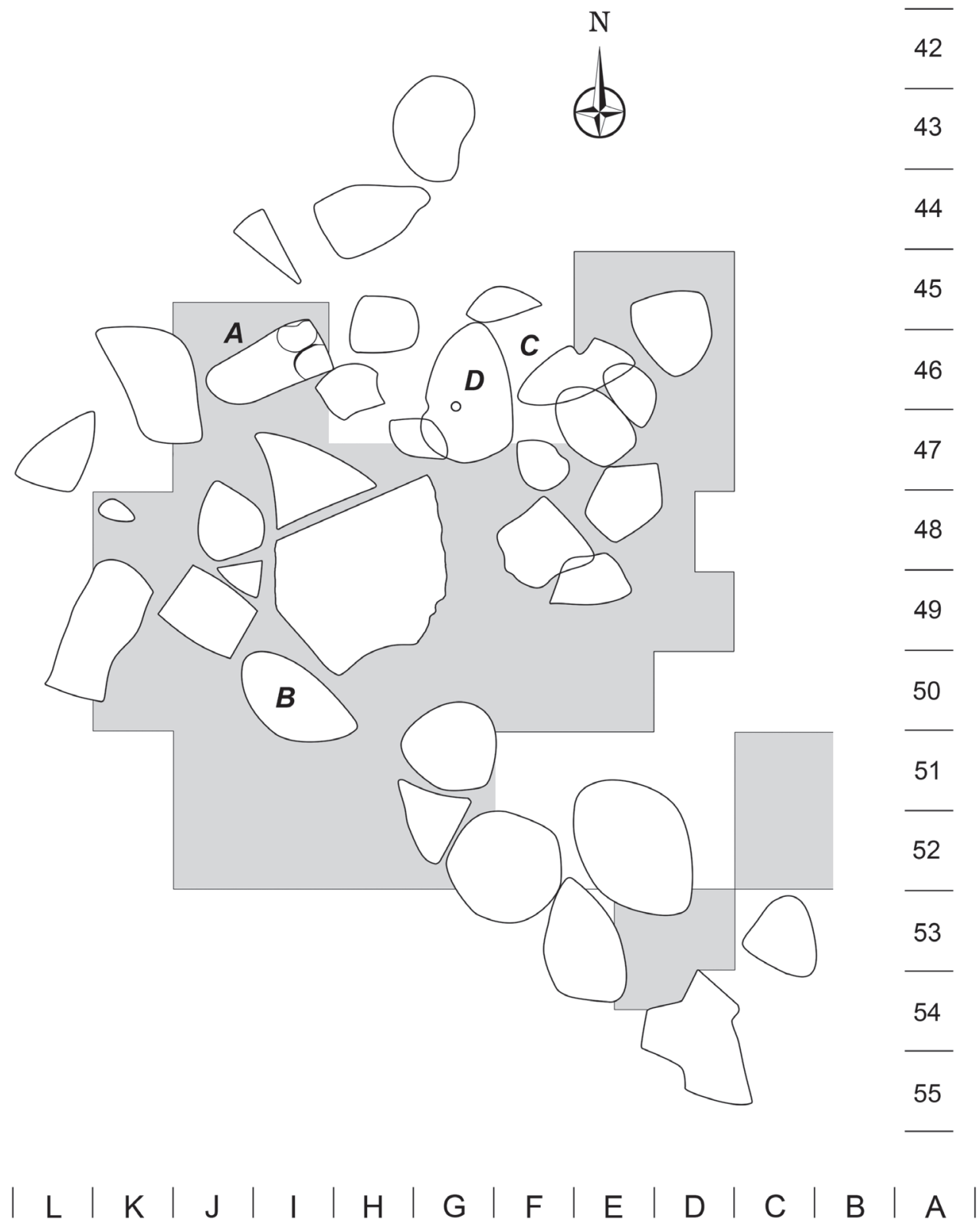

Obr. 8. Plán ústřední skupiny balvanů u III. revíru. Zaměřil P. Neruda, grafika T. Janků.

Abb. 8. Plan der Zentralgruppe von Steinblöcken am III. Revier. Messung P. Neruda, Grafik T. Janků. 


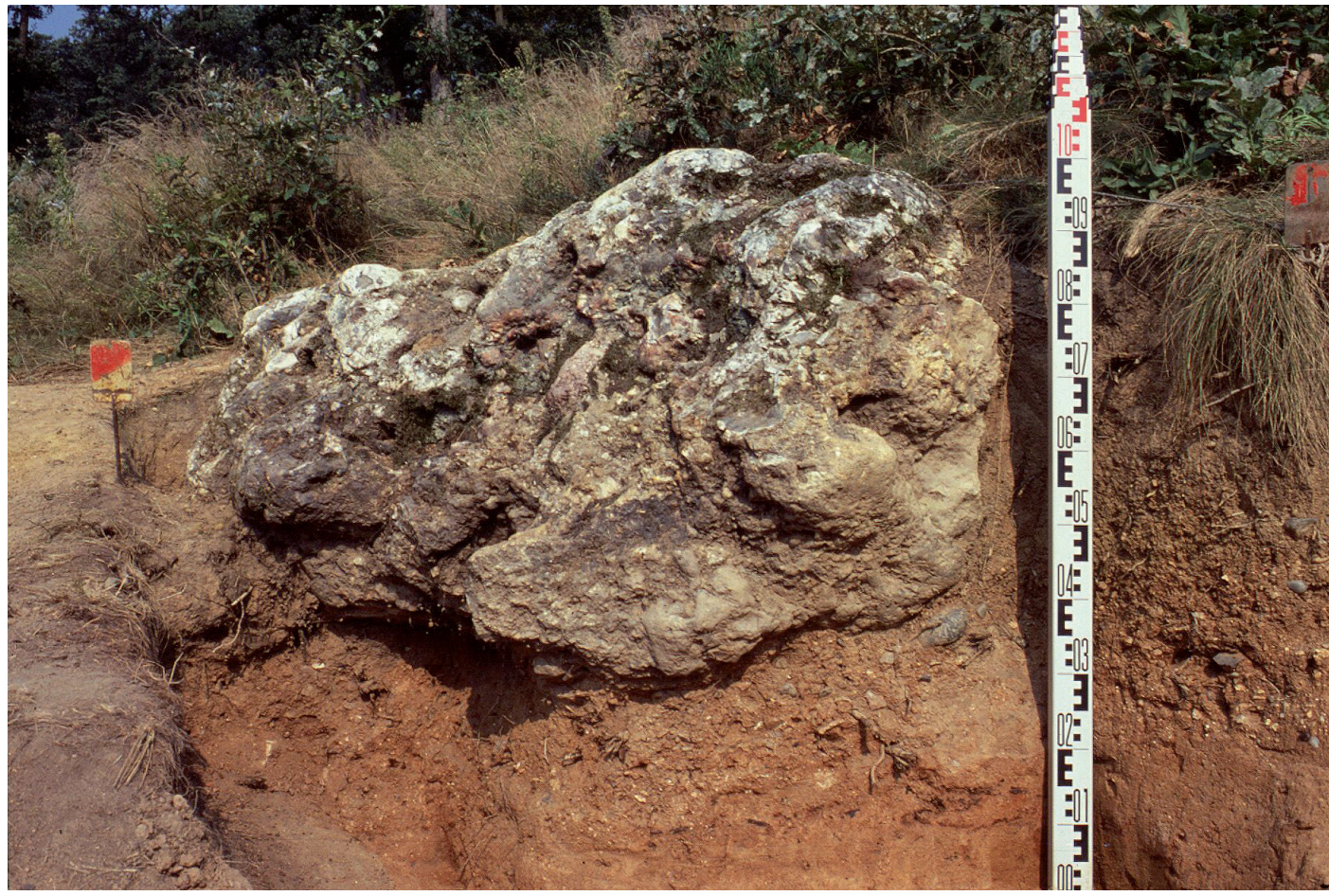

Obr. 9. Blok rohovcové brekcie, přemístěný na vrstvu se štípanou industrií pod vrcholem svahu s těžebním revírem VI. Foto M. Oliva.

Abb. 9. Block der Hornsteinbrekzie, auf die Schicht mit Spaltindustrie unterhalb des Gipfels des Hangs mit dem Abbaurevier VI versetzt. Foto M. Oliva.

náročných činnostech bez praktického významu, za to s markantními sociálními a religiózními konotacemi (Oliva 2019). Činnosti tohoto druhu jsou ostatně zodpovědné za vznik jak většiny skalních rytin, tak megalitů. Je proto pravděpodobné (ale nikoli jisté), že manipulace s kameny v jižní skupině těžebních areálů probíhala ve starší době bronzové. Nešlo totiž o jev náhodný, nýbrž velmi pracný a proto záměrný. Nabízí se srovnání se stovkou nápadných kamenů v českých zemích, svévolně označených jako menhiry, z nichž pouze jeden je doplněn (spornou a možná recentní) rytinou, u jednoho se našel zlomek sekeromlatu, a pravěká či středověká keramika se u nich nevyskytla vůbec (Zemek 2009, 105, 137). Totéž se týká tzv. kounovských řad, opakovaně vydávaných za pravěké kamenné aleje, a to dokonce i renomovanými autory (Cílek 2014). Souvislost výrazných kamenů a nápadných kopců s pravěkými památkami je přitom uznávána nejen zkušenými amatéry (Dubský 1949, 222-229), ale i předními archeology v základních kompendiu českého pravěku (Jiráň et al. 2008, 237). Historické prameny dokládají, že úcta prokazovaná kamenům přežívala až do křestanských dob, kdy ji církev usilovně vyvracela a kameny včetně megalitů ničila (Krzak 1994, 344-359). Mezi 5. až 8. stoletím odsoudilo ctění kamenů nejméně 6 synod a koncilů (Zibrt 1894, 38-40). Kronikář Kosmas si stěžuje, že Tetka „navedla hloupý a nerozumný lid .... aby se klaněl há- 


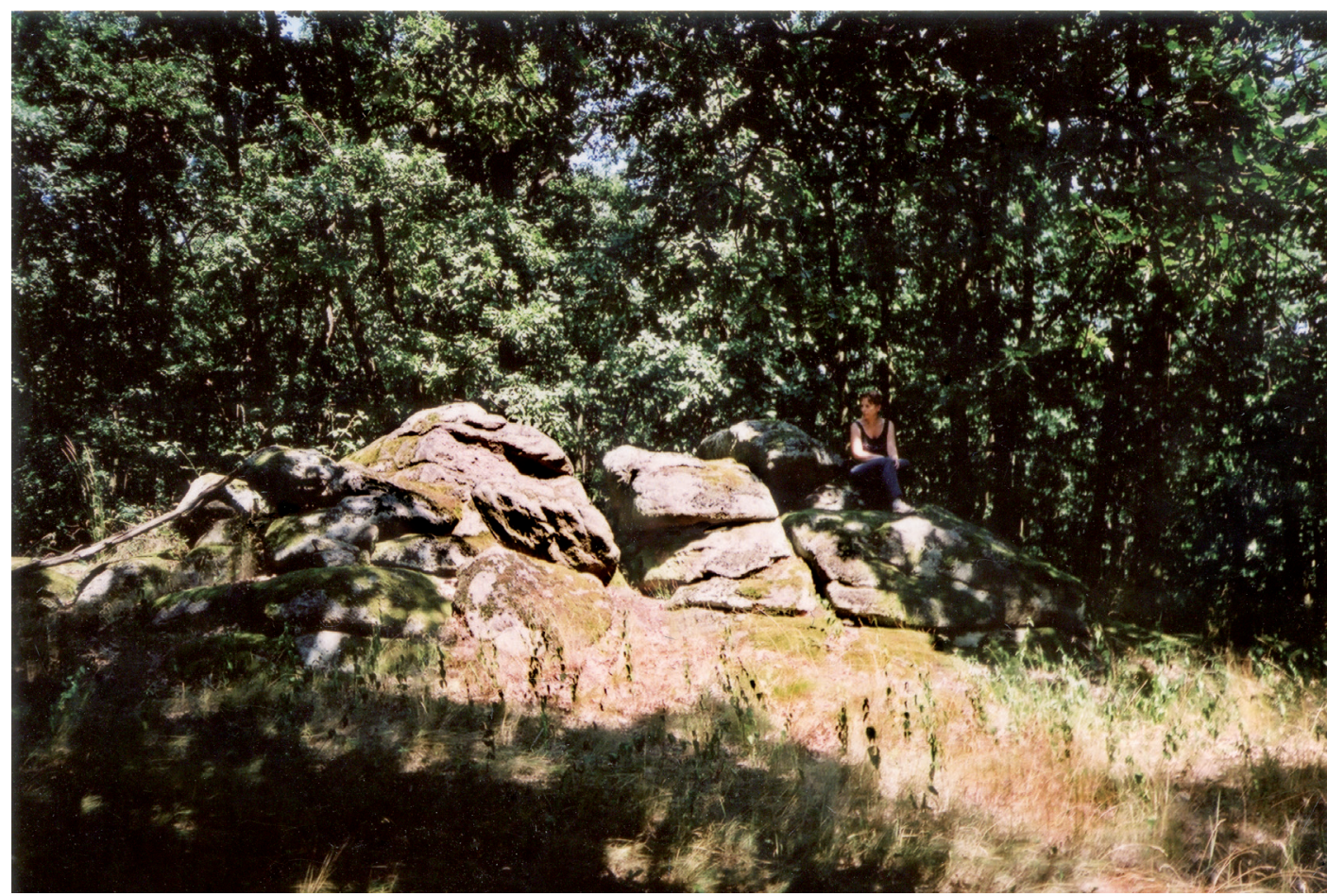

Obr. 10. Skalka na JV okraji plošiny Krumlovského lesa s nálezem depotu kruhovitých hřiven starší doby bronzové. Foto M. Oliva.

Abb. 10. Felsen mit Hortfund der altbrozezeitlichen Barrenringe. Foto M. Oliva.

jům, stromům a kamenům“ (Kosmova kronika česká, 1949, 19).

Př́klad Krumlovského lesa na druhé straně ukázal, že ani v oblasti s nanejvýš př́íznivými přírodními předpoklady (výskyt nápadných skalek i volných přemístitelných bloků), ležící uprostřed bohatého pravěkého osídlení, frekventované velmi intenzívní činností především symbolického významu (těžba nepoužívaného kamene, restituce krajiny $\mathrm{v}$ době bronzové), která se díky tisícileté tradici této činnosti a nahromaděním krajinných antecedentů po předcích jistě stávala krajinou posvátnou, nedošlo $\mathrm{k}$ výraznějšímu dialogu člověka s přírodními skalními útvary. Kromě zmíněných jevo̊ lze uvést ještě nejasné zprávy o detektorářských nálezech pod okraji balvanů (obr. 10; Oliva 2019, mapa 1: 17), avšak s fenoménem megalitizmu, jak jej známe ze západní Evropy, mají dokumentované jevy jen pramálo společného - žel asi ne více než tzv. menhiry z Čech (kriticky Sklenár 1984).

Předložená práce vznikla za finanční podpory Ministerstva kultury v rámci institucionálního financování na dlouhodobý koncepční rozvoj výzkumné organizace Moravské zemské muzeum (DKRVO, MK00009486202). 


\section{Bibliografie}

Cílek, V. 2014: Kameny a hvězdy. Síly předků, oči kamenů, světla odjinud. Praha.

Dehn, W. 1981: „Heilige“ Felsen und Felsenheiligtümer. AFD Beiheft 16, Beiträge zur Ur- und Frühgeschichte I, 373-384. Berlin.

Dubský, B. 1949: Pravěk jižních Čech. Blatná.

Demek, J. 1960: Formy zvětrávání a odnosu žuly v Krumlovském lese jihozápadně od Brna, Časopis pro mineralogii a geologii 5, 240-246 a 8 tab.

Demek, J. - Mackovčín, P. edd. 2006: Hory a nížiny. Zeměpisný lexikon. Brno.

John, J. 2003: Spony, náramky, hradiště a mohyly. Příklad materiální paměti komunit doby laténské. In: L. Šmejda - P. Vařeka (edd.): Sedmdesát neustupných let, 79-84. Plzeň.

Kañáková-Hladiková, L. 2013: Posteneolitická štípaná industrie na Moravě. DABP 15, Brno.

Kosmova kronika česká, 1949. Přeložil Karel Hrdina. Praha.

Krzak, Z. 1994: Megality Europy. Warszawa.

Migoň, P. - Roštinský, P. 2003: The granite landscape of the Krumlovský les Forest, South Moravia: An emample of a variety of structural controls, Moravian Geographical Reports 11/1, 36-44.

Neruda, P. - Nerudová, Z. edd. 2009: Krumlovský les IV. Vícevrstevná lokalita ze středního a počátku mladého paleolitu na Moravě. Anthropos NS 21, Brno.

Oliva, M. 2003: O nezanedbatelnosti neočekávatelného: štípané industrie starší doby bronzové na Moravě, Archeologické rozhledy 55, 10-46.

Oliva, M. 2010: Pravěké hornictví v Krumlovském lese. Vznik a vývoj industriálně-sakrální krajiny na jižní Moravě. Anthropos 32 /N.S. 24/, Brno.

Oliva, M. 2015: Mezolitická těžba rohovce v Krumlovském lese v kontextu neolitizace střední Evropy, Památky archeologické 106, 5-42.

Oliva, M. 2019: Těžba a rituál, pamět a transformace. Uzavírky šachet a obětiny $\mathrm{z}$ doby bronzové v Krumlovském lese. Anthropos Studies 40 /N.S. 32/, Brno.
Oliva, M. 2020: Krumlovský les II-east: Recent excavations of the Mesolithic mining area, Acta Musei Moraviae, scientiae sociales 105/2, 167-179.

Přichystal, A. 2009: Kamenné suroviny v pravěku východní části střední Evropy. Brno.

Přichystal, A. 2010: Geologie území a petrografická analýza rohovců z Krumlovského lesa. In: M. Oliva: Pravěké hornictví v Krumlovském lese, 385392. Brno.

Roštínský, P. 2009: Geomorfologická charakteristika okolí archeologické lokality Moravský Krumlov IV. In: P. Neruda - Z. Nerudová edd.: Krumlovský les IV. Vícevrstevná lokalita ze středního a počátku mladého paleolitu na Moravě, 26-42. Brno.

Rzehak, A. 1906: Die Schalensteine („Opfersteine“) im westmährischen Granitgebiet, Zeitschrift d. Mähr. Landesmus. VI, 235-290.

Sklenář, K. 1977: Slepé uličky archeologie. Praha.

Sklenářr, K. 1984: Ještě k otázce českých menhirů, Památky a příroda $9,557-562$.

Skutil, J. 1947: K domnělému pravěkému stáří t.zv. „obětních kamenů“. Věda a život 13, 93-94.

Stuchlik, S. 2001: Nadzemní kůlové stavby ze starší doby bronzové na Moravě, Pravěk NǨ 10, 2000, 219-250.

Stuchliková, J. 1990: Výzkum fortifikace na sídlišti v Budkovicích, Archeologické rozhledy 42, 121143.

Waldhauser, J. 1994: Dodatek ke stati J. Blažka o laténské sponě z Oblíku v severozápadních Čechách, Archeologické rozhledy 46, 464-465.

Waldhauser, J. - Koldová, K. 2006: Mimořádné aktivity Keltů na skalním útvaru Sokolka v Pojizeří, Archeologie ve středních Čechách 10, 555-598.

Woldřich, J. N. 1896: Předhistorické výzkumy v jihovýchodních Čechách. Památky archeologické XVII, 159-175.

Zemek, R. 2009: Neznámé menhiry v Čechách a na Moravě. Olomouc.

Zibrt, Č. 1894: Seznam pověr a zvyklostí pohanských z VIII. věku. Rozpravy České akademie. Praha (reprint 1995). 


\section{Hergerichtete Aufschlüsse und die Megalitenfrage im Abbaurevier des Kromauer waldes (Südmähren)}

Mit auffallenden Felsen und verschiedenen Vertiefungen und Rillen wurden immer Vorstellungen von Opfersteinen und mysteriösen Inschriften verknüpft. In Mähren kommen sie jedoch immer im bergigen Terrain zum Vorschein, also abseits der urzeitlichen Besiedlung (Rzehak 1906; Skutil 1947). Eine Ausnahme bildet das Hügelland des Kromauer Waldes in Südmähren. Sein Liegende bilden Granodiorite (Abb. 2-4), auf welchen jurassische Kalksteine beruhten, die später denudiert wurden. Davon erhielten sich nur Hornsteine, die in Sedimente des Miozänmeeres redeponiert wurden. Die bildeten immer die Grundlage gespaltener Industrien in der breiten Umgebung und wurden von dem Mesolithikum bis zur älteren Eisenzeit intensiv abgebaut (Oliva 2010). Der Höhepunkt der Förderung fällt in die ältere Bronzezeit, wenn hier die Gipfelteile zweier Nachbarkämme abgebaut und später wieder angehäuft wurden (Oliva 2019). In der Abbauphase wurden dort Hunderte Schächte von einigen Metern Tiefe und Durchchmesser abgeteuft und eine beträchtliche Menge Spaltindustrie hergestellt. Diese Tätigkeit fand ihren Höhepunkt am Ende des Prozesses der Rückhäufung des abgebauten Materials (Abb. 1), weil die größte Menge der Spaltindustrie immer in Oberschichten der Halde vorkommt. Seit dem Ende des Eneolithikums wurde der Abbau eher durch gesellschaftliche und religiöse als praktische Beweggründe motiviert, denn fast der ganze Ertrag, gespaltet oder nicht, blieb an Ort und Stelle in Tausenden Tonnen. Einige Blöcke dienten den urzeitlichen Spaltern als Sitzsteine, weil sie mit Produktionsabfall umgeben sind. Auf einem dieser Sitzsteine ist ein regelmäßiger Ring geritzt und in Spalten darunter wurden kleine Scherben der Aunjetitzer Kultur gefunden (Abb. 5). Der Block in einer anderen auffallenden Gruppe (Abb. 6, 8) mit zwei geritzten Ringen (Köpfen?) war ursprünglich wohl aufgerichtet (Abb. 7). Auf auffallenden Felsen konnten keine Eingriffe festgestellt werden. Ein metergroßer Block der Hornsteinbrekzie (Abb. 9) liegt jedoch auf dem Sediment mit Abschlägen und wurde dorthin wohl während der jüngeren Stufe der Lengyelkultur gebracht, weil in Schacht $\mathrm{Nr} 4$, dessen Mündung sich $8 \mathrm{~m}$ hangabwärts öffnete, Skelette zweier kleiner Frauen und eines Neugeborenen mit einer Junglengyelfußschale gefunden wurden (Oliva 2010, Plan 3, Photo CVIII, 29 ff.) Es ist also offensichtlich, dass Felsen und Steinblockgruppen einen wichtigen Bestandteil der Sakrallandschaft bildeten, es kann also von direkten Zusammenhängen mit dem westeuropäischen Megalitismus nicht gesprochen werden. 
Oliva

\section{doc. PhDr. Martin Oliva, Ph.D., DSc.}

- Moravské zemské muzeum - Ústav Anthropos

Zelný trh 6, 65937 Brno, CZ

moliva@mzm.cz 